June 2017

\title{
Structure and Significance
}

\section{Tamarack Hockin}

San Jose State University, tamahoc@gmail.com

Follow this and additional works at: https://scholarworks.sjsu.edu/ischoolsrj

Part of the Cataloging and Metadata Commons, Scholarly Communication Commons, and the Scholarly Publishing Commons

\section{Recommended Citation}

Hockin, T. (2017). Structure and Significance. School of Information Student Research Journal, 7(1). https://doi.org/10.31979/2575-2499.070101 Retrieved from https://scholarworks.sjsu.edu/ischoolsrj/ vol7/iss $1 / 1$

This article is brought to you by the open access Journals at SJSU ScholarWorks. It has been accepted for inclusion in School of Information Student Research Journal by an authorized administrator of SJSU ScholarWorks. For more information, please contact scholarworks@sjsu.edu. 


\section{Structure and Significance}

About Author

Tamarack Hockin holds an MLIS and Advanced Certificate in Digital Assets and Services from the School of Information at San Jose State University, and was Editor-in-Chief for the SLIS Student Research Journal (2016-2017). 
This issue of the SLIS Student Research Journal features two articles addressing schema, structure, and theory in LIS. In an invited contribution, Dr. Mary Bolin proposes applying linguistic theories and frameworks to LIS research. Bolin states that librarians "already recognize the significance of the language that we use" ( $p$. 1), and suggests that interdisciplinary methods may strengthen investigations in areas of LIS research concerned with semantic structures and communicative events. Bolin suggests numerous convergences between the disciplines: how typology may be used for parsing qualitative data, or semantic frames for examining relationships and meaning in metadata schemas; discourse analysis and genre theory also offer intriguing possibilities for examining user communities in library contexts.

In our peer-reviewed section, MLIS candidate Chloe Noland evaluates the interoperability of Library of Congress Classification and Elazar at two libraries of the American Jewish University. Noland compares bibliographic metadata from the two collections, considering semantic accuracy and user impacts. Noland determines that although in the academic context it is unclear which classification system may be preferable, "for purposes of Jewish themes and subjects...Elazar overwhelmingly provides the best specificity" (p. 12). This article will be of interest to special collections librarians and cataloguing and metadata specialists.

This thirteenth issue of the $S R J$ closes my tenure as Editor-in-Chief with the journal. It has been a year of significant development in organizational planning, yielding a refreshed strategic plan for the $S R J$, revisions to our recruitment, orientation, training for editors, and the launch of a new peer-reviewed reviews section for the journal. These accomplishments build on the work of 50 student editors who have contributed to the SLIS Student Research Journal since its establishment in 2010. Student editors have designed the journal's aims and scope, planned operations, reviewed and edited manuscripts, promoted the $S R J$ to a diverse readership, and built the journal's reputation. The $S R J$ is distinct as the only student governed, double-blind peer reviewed MLIS journal in North America publishing graduate student scholarship. Strong operations and governance at the $S R J$ have produced more than 50 refereed articles over seven years. However, the $S R J$ has also provided a unique forum for MLIS candidates to experience scholarly communication as editors, reviewers, teammates, and managers.

\section{Acknowledgements}

The opportunity to work for the $S R J$ as Editor-in-Chief has been the highlight of my MLIS; it has brought depth and theory into my academic experience. The accomplishments of my tenure as EIC were supported by a team of dedicated editors, and the exceptional educational support and guidance of Dr. Anthony Bernier in his role as SRJ Faculty Advisor. I am also grateful to Dr. Michelle Riedlinger and Dr. Linda Pardy from the University of the Fraser Valley, who encouraged me to pursue my academic interests and become the first in my family to complete a master's degree. 